Piotr Stańczyk

Uniwersytet Gdański

email: pedps@univ.gda.pl; piotr.stanczyk@ug.edu.pl

\title{
Freire versus Foucault: plantacje, niewolnictwo i pedagogika rzeczy
}

\begin{abstract}
STRESZCZENIE
Zasadniczym celem artykułu jest dokonanie porównania filozofii wychowania Paula Freirego i Michela Foucaulta na przykładzie akcji alfabetyzacyjnej w Demokratycznej Republice Wysp Świętego Tomasza i Książęcej (STP). Używając archeologii wiedzy autor zamierza odkryć warstwy tekstualne. Pierwsza z warstw zawiera analizę tekstów (z początku XX wieku), jak raporty na temat warunków pracy w quasi-niewolniczym systemie w portugalskich plantacjach oraz odpowiedzi publikowane przez portugalskich plantatorów. Organizacja pracy oraz opisy rdzennych robotników z tego okresu są zbliżone do Foucaultowskiej koncepcji nadzorowania i karania. Druga z warstw zawiera analizę tekstów z Freirowskiej akcji alfabetyzacyjnej. Jednakże użycie koncepcji Foucaultowskiej do analizy tekstów z podręczników z okresu akcji alfabetyzacyjnej pomniejsza sens pedagogiki emancypacyjnej. W konkluzji autor stara się oddalić - z pragmatycznego punktu widzenia - możliwą krytykę koncepcji Freirego przy pomocy koncepcji Foucaulta, znajdując rozwiązanie w emancypacyjnej pedagogice rzeczy.

SŁowA Kluczowe: Paulo Freire, Michel Foucault, pedagogika emancypacyjna, nadzorować i karać, pedagogika rzeczy, pedagogika materialistyczna
\end{abstract}

Celem tego artykułu jest porównanie edukacyjnych implikacji, wynikających z filozofii Michela Foucaulta i Paula Freirego na konkretnym przykładzie przemian organizacji pracy oraz przestrzeni terenów nisko zurbanizowanych w Demokratycznej Republice Wysp Świętego Tomasza i Książęcej (dalej: STP). Uzasadnienie tego celu - od strony Freirego (1978) - jest dość oczywiste i wynika z tego, że ten brazylijski edukator i filozof wychowania miał swój walny udział w procesie alfabetyzacji w okresie dekolonizacji i młodej niepodległości STP. Akcja alfabetyzacyjna była jedną z wielu ambitnych reform, zmierzających do reafrykanizacji STP, czyli do usunięcia kolonialnych naleciałości w organizacji społeczeństwa. Natomiast powiązanie Foucaulta (2000a, 200ob, 2009, 2010) z przemianami społecznymi, a szczególnie przemianami przestrzeni terenów wiejskich na STP jest już tylko teoretyczne i bierze się z tego, że organizacja dawnych portugalskich plantacji (port. roças) przypomina 
organizację społeczeństw wyłożoną w Nadzorować i karać. W tym kontekście zadam pytanie o potencjał krytyczny i potencjał zmiany społecznej obu interesujących mnie tutaj koncepcji - koncepcji przedstawiających mechanizmy dominacji. Mówiąc inaczej, spojrzę z perspektywy Foucaulta na teren interwencji pedagogicznej organizowanej przez Freirego, co w konsekwencji pozwoli sformułować wątpliwości odnośnie myśli Foucaulta, a właściwie jej potencjału do inicjowania krytycznej, radykalnej i emancypacyjnej zmiany społecznej.

Krytyka praktycznych ograniczeń teorii - w kontekście inicjowania zmiany społecznej - nie jest niczym nowym po krytycznej, radykalnej i emancypacyjnej stronie sceny teoretycznej. Przykładem takiej krytyki jest choćby spór między Maxem Horkheimerem (1985) i Karlem Mannheimem (1992) o pojęcie ideologii, w którym Horkheimer zarzuca Mannheimowi, iż przez rozszerzenie zasięgu krytyczności, tak „by marksizm wniknął sam w siebie i poznał także i swoją ideologiczność" (Horkheimer, 1985, s. 413) pojęcie ideologii traci swój krytyczny potencjał, gdyż traci potencjał emancypacyjny przez zrównanie ideologii panującej z emancypacyjną. Podobny spór, który dotyczył determinacji w ostatniej instancji przez ekonomię podzielił Ernesto Laclau i Slavoja Žižka, gdzie ten pierwszy o pryncypialności drugiego pisał jako o „czekaniu na Marsjan”, podważając praktyczność koncepcji Žižka (Laclau, 2009, s. 197-203), ten drugi zaś podważał sensowność części projektów kontrhegemonicznych, gdyż nie jest obojętne, z jaką odmianą populizmu mamy do czynienia (Žižek, 2008, s. 63-147). Spór o praktyczność teorii prowadził również Henry Giroux (1983, 2001), kwestionując potencjał do inicjowania zmiany społecznej teorii reprodukcji (Bourdieu, Passeron, 2006; Bernstein, 1990; Bowles, Gintis, 1976, 2002; Althusser, 2006). Prototypem tych sporów są walki prowadzone przez Karola Marksa i Fryderyka Engelsa, które - co szczególnie ważne dla tego tekstu - stanowią asumpt dla stworzenia projektu pedagogiki materialistycznej (Suchodolski, 1957). Jeżeliby spróbować wyrazić złożone poglądy Marksa w tej materii, to najlepiej sięgnąć do 11. tezy o Feuerbachu, która brzmi jak hasło programowe: „Filozofowie rozmaicie tylko interpretowali świat; idzie jednak o to, aby go zmienić" (Marks, Engels, 1981, s. 196).

Co jednak ważniejsze i co stanowi kluczowy kontekst dla prowadzonego tu wywodu, to to, że wspomniane powyżej spory, oprócz problematyki zmiany społecznej, mają za swój przedmiot zagadnienie relacji pomiędzy tym, co w relacjach społecznych materialne i tym, co niematerialne - pomiędzy materialną bazą i ideologiczną nadbudową, rzeczą i dyskursem. Jest to spór o determinację bytu społecznego w ostatniej instancji przez material- 
ność i jego dyskursywną naddeterminację. Dlatego też nie sposób nie odnieść się do obiecującego przesilenia paradygmatycznego, które dzieje się na naszych oczach i polega na (ponownym) włączeniu do refleksji pedagogicznej zagadnienia relacji między ludźmi i rzeczami. Pedagogika rzeczy jest szansą na przezwyciężenie problemu, który za Bogdanem Suchodolskim (1957, s. 272-273) określić można jako „złudzenie pedagogiczne”, które za swą istotę ma pogląd o szczególnej i samoistnej roli edukacji w procesie zmiany świata. Taka dominująca pośród pedagogów - postawa intelektualna polega na przekonaniu, że każda zmiana społeczna zależy od zmiany świadomości, a takie podejście do problemu zmiany społecznej lokuje władzę dyskursu nad władzą, jaką nad indywidualnym i zbiorowym życiem ma materialność. Opozycyjny względem „złudzenia pedagogicznego” pogląd brzmi, że trwała i produktywna zmiana świadomości może być dokonana poprzez proces dokonywania zmiany warunków życia, które mają postać materialną.

Wracając jednak do samego zwrotu w stronę materialności w teorii edukacji, to z jednej strony oczywiste wydają się inspiracje marksistowskie, ale $\mathrm{z}$ drugiej ten paradygmatyczny przewrót swoje korzenie ma i w myśli Foucaulta (m.in. 2009), a także w myśli Bruno Latoura (2010, 2011). Gert Biesta (2010), inspirujący się Jaques'em Rancière’em (1991), ów zwrot ku rzeczy określa w kategoriach pedagogiki post-krytycznej, podobnie jak dzieje się to w pracy Jorisa Vlieghe'a (2016). Koncept pedagogii skoncentrowanej na rzeczach (ang. thing-centred pedagogy) przedstawiany jest również w pracach, których Vlieghe jest współautorem (Hodgson, Vlieghe, Zamojski, 2017a, 2017b). Koniecznie należy tu podkreślić, że problematyka pedagogiki rzeczy dynamicznie rozwijana jest również w polskiej pedagogice, czego dobrym przykładem są prace szczecińskich pedagogów (Chutorański, 2015, 2016, 2017; Chutorański, Makowska, 2016; Szwabowski, 2016), czy też prace wspomnianego już Piotra Zamojskiego oraz Karoliny Starego (2016) ze środowiska gdańskiego.

W tym artykule patrzę przez pryzmat pedagogiki rzeczy na działalność oświatową Freirego - uznaję jego dokonania za przykład dobrych praktyk radykalnej, krytycznej i emancypacyjnej pedagogiki rzeczy. Takiej pedagogiki, która ma ewidentne źródła w inspirowanej materializmem dialektycznym koncepcji Suchodolskiego, zwanej pedagogiką materialistyczną. Na czym polega ta odmiana pedagogiki rzeczy, przedstawię w opozycji do koncepcji Foucaulta, która wprawdzie jest krytyczna, ale - moim zdaniem - ma bardzo ograniczony potencjał emancypacyjny. Materiałem, który posłuży do przeprowadzenia tego porównania będą: opisy i dokumentacja fotograficzna portugalskich plantacji na STP z przełomu XIX i XX wieku; materiały z cy- 
klu podręczników do alfabetyzacji i post-alfabetyzacji z drugiej połowy lat 70. oraz lat 8o.; także współczesna dokumentacja fotograficzna.

Przełom XIX i XX wieku jest szczególnie ważny dla omawianego problemu, gdyż światowa opinia publiczna zwróciła wtedy uwagę na bestialskie sposoby postępowania kolonów wobec ludności rdzennej w krajach należących do potęg kolonialnych. Jednym z najsłynniejszych raportów o warunkach życia i pracy ludności rdzennej był raport Rogera Casementa (1904) z terenów tzw. Konga Belgijskiego. Warunki pracy i życia na STP zostały natomiast ujawnione międzynarodowej opinii publicznej w raporcie opublikowanym w 1907 roku przez pracującego dla braci Cadbury - Josepha Burtta (Higgs, 2012). Natomiast opisy, które powstały na zlecenie portugalskich plantatorów miały przedstawiać międzynarodowej opinii publicznej plantacje w dobrym świetle, uzasadniając również rozwiązania z zakresu organizacji pracy. Wobec czego, niniejszy artykuł stanowi ćwiczenie z Foucaultowskiej (2002) archeologii wiedzy, gdzie odkrywam teksty z okresu wzmożonej dyskusji o warunkach życia rdzennej ludności pod panowaniem portugalskim, by później spojrzeć na akcję alfabetyzacyjną Freirego. Artykuł zamknięty będzie omówieniem kontrowersji pojawiających się na styku obu koncepcji.

\section{Portugalskie plantacje: nadzorować i karać}

Wyspa Świętego Tomasza oraz Wyspa Książęca zostały odkryte w drugiej połowie XV wieku i wtedy skolonizowane przez Portugalczyków pochodzących głównie z Madery (Monteiro de Mendonça, 1907, s. 9). Na przełomie XV i XVI wieku następuje intensyfikacja handlu ludźmi, którzy pochodzą z „Wybrzeża Niewolniczego” (port. Costa dos Escravos) - jak nazywany jest region ujścia rzeki Niger przez kolonialny reżim (Caldeira, 1999, s. 22-23). Inne źródła wskazują również obszar obecnego Gabonu jako miejsce, skąd pochodzą saotomejscy niewolnicy, lecz są oni sprowadzeni już po formalnym zniesieniu niewolnictwa (Frynas, Wood, Oliveira, 2003, s. 53; Almada Negreiros, 1895, s. 11-12). W tym czasie STP staje się centralą handlu niewolnikami i - jak określa to Arlindo Manuel Caldeira (s. 24) - targiem koncentracyjnym (port. mercado do concentração) w drodze niewolników do Antyli. Gospodarka STP w tamtym okresie (do XVII wieku) bazuje na handlu ludźmi, niewolnictwie i uprawie trzciny cukrowej, a później przechodzi w stronę dywersyfikacji upraw (s. 28-29), ale od XVIII wieku znów uzależniona jest od dwóch dóbr eksportowych (wpierw kawy, potem kakao) do tego stopnia, że badacze również określają to monokulturą (Frynas i in., 2003, s. 53-56; Pape, Rebelo de Andrade, 2015, s. 234-235). Powoduje to, że portugalskie plantacje na STP są wrażliwe na zmiany koniunktury światowej. Co jednak 
ważniejsze, to to, że gospodarka oparta na niewolnictwie uzależniona jest również od czynników demograficznych, a w XVII wieku wybucha kryzys demograficzny pośród, stanowiących większość populacji STP i źródło siły roboczej, Afrykańczyków (Caldeira, 1999, s. 42). Przyczyny tego kryzysu stanowią nadmierny eksport, niedostateczny import niewolników, wysoki wskaźnik śmiertelności i niedostatecznie wysoki wskaźnik urodzin. Handel niewolnikami zostaje zakazany $\mathrm{w} 1836$, a samo niewolnictwo $\mathrm{w} 1858$ roku przy zachowaniu... dziesięcioletniego okresu przejściowego, podyktowanego względami kapitalistycznej już wtedy gospodarki, która załamałaby się ze względu na brak siły roboczej. Właściciele plantacji łamią zakaz handlu i posiadania niewolników, sprowadzając w 1864 roku niewolników z Gabonu, po tym, jak na STP wybucha epidemia ospy (Frynas i in., 2003, s. 53). Brak siły roboczej staje się chronicznym problemem kolonów, w czym nie pomaga tworząca się od XVII wieku kultura forros, czarnych wyzwoleńców. Przy tym, położenie społeczne Saotomejczyków, ich warunki życia czy prawa publiczne ulegają, pomimo abolicji, tylko niewielkiej poprawie. Gerhard Siebert zniesienie niewolnictwa określa jako przejście od systemu wyzysku niewolniczego do systemu wyzysku kapitalistycznego (1999, s. 32-41). Pogląd Sieberta jest dyskusyjny w miejscu, w którym zarysowuje on wyraźny podział pomiędzy systemem niewolniczym i kapitalistycznym, gdyż - jak choćby wskazuje Thomas Piketty (2015, s. 194-201) - niewolnicy są jedną z form kapitału, a więc kapitalizm silnie powiązany jest z niewolnictwem. Mówiąc wprost, niewolnictwo i kolonialne podboje w Nowym Świecie stanowią zbrodniczą formę akumulacji kapitału, co zresztą dostrzega i Freire, pisząc o „komercyjnym duchu kolonizacji” (1967, s. 71-72).

Problem braku siły roboczej wynikał z tego, że Saotomejczycy, gdy tylko mieli ku temu sposobność, rezygnowali z pracy na plantacjach. Po zniesieniu niewolnictwa administracja kolonialna wprawdzie wprowadzała rozwiązania sprzyjające portugalskim kolonom, jak choćby praca przymusowa robotników kontraktowych (port. serviçais) (sprowadzanych początkowo z Angoli, później z Wysp Zielonego Przylądka i Mozambiku, a nawet z odległej portugalskiej kolonii Makau), ale i ci, gdy tylko nadarzała się okazja, opuszczali plantacje. Wprawdzie najczęściej nie byli w stanie wrócić do swoich ojczyzn - ich zarobki nigdy by na to nie pozwoliły - ale wybierali życie poza plantacjami, stanowiąc rezerwuar oporu i dając później impuls do walki z portugalskim uciskiem i walki o niepodległość oraz reafrykanizację STP. Jak podają źródła, pomimo przypływu pracowników kontraktowych liczba pracowników plantacji stopniowo zmniejszała się - z 38000 w 1921 do 17000 w 1954 roku (Frynas i in., 2003, s. 54). Cytując Foucaulta (2009, s. 101): „Jakaś 
tajemna, podobna do ciążenia siła popycha nas zawsze ku przyjemności. Odruchowi temu stoi na przeszkodzie tylko przeciwstawiające mu się prawo. Wszystkie rozliczne ludzkie działania są wynikiem tej naturalnej skłonności”. Dodając w kolejnym zdaniu: „Znalezienie odpowiedniej kary dla zbrodni jest równoznaczne ze znalezieniem dolegliwości, której przedstawienie całkowicie pozbawiałoby atrakcyjności przedstawienie złego czynu" (s. 101). Taką właśnie wizję kultury wyzwoleńców mieli portugalscy koloni i kolonialna administracja do Rewolucji Goździków w 1974 roku i uzyskania przez STP niepodległości w 1975. Restrykcjom podlegał właściwie każdy obszar życia Saotomejczyków, każda praktyka kultury ludowej, która została uznana przez faszystowski i rasistowski reżim za działalność obniżającą wydajność pracy, czy odciągającą ludzi - a faktycznie tanią siłę roboczą - od pracy w portugalskich majątkach ziemskich. Lista zakazów była długa i obejmowała tak ludowe święta, jak i naukę czytania i pisania poza systemem szkolnym, tak tańce ludowe, jak i produkcję wina palmowego.

Pierwsze, interesujące tu nas spostrzeżenie poczynione przez Foucaulta - dotyczy wzmiankowanego już założenia, że ludzie są źli z natury. Drugim istotnym elementem Foucaultowskiego (2009, s. 7-25) opisu tranzycji do spoleczeństwa nowoczesnego jest przejście od kaźni do karania, które pojmowane jest jako "technika amelioracji” i ma za zadanie "poprawiać”, „wychowywać” i „leczyć” podmiot (s. 13). Kara staje się wtedy taktyką polityczną, „technologią władzy" opartą na blokowaniu ciała i ujarzmieniu człowieka (s. 25). Po trzecie, analizując przejście od kolonialnego systemu plantacji do niepodległości STP, nie można pominąć czynnika „ekonomii politycznej ciała”, w której „chodzi (...) o ciało - o ciało i jego siły, o ich podatność i przydatność, ich rozdysponowanie i podporządkowanie" (s. 26-27). Mówiąc wprost - choć to radykalna interpretacja autora Nadzorować $i$ karać - ostatecznym punktem odniesienia pozostaje ciało i jego materialność, bo władza dyskursu nie jest potrzebna sama sobie, lecz by ujarzmiony podmiot - nawiązując do Louisa Althussera (2006) - maszerował tam, dokąd skierują go warstwy uprzywilejowane, ze swoją uprzywilejowaną kulturą i ze swoimi uprzywilejowanymi interesami, które, choć partykularne, to urastają do rangi interesu powszechnego. Czwartym kluczowym elementem koncepcji Foucaulta jest mechanizm panoptyczny, który umożliwia nadzór nad złymi z natury, opornymi wobec pracy, ale faktycznie opornymi wobec wyzysku, ujarzmianymi podmiotami. Wszystkie te cztery elementy odnajdziemy w zasadach organizacji portugalskich plantacji.

W opublikowanej w 1906 i przetłumaczonej w 1907 roku na język angielski monografii o plantacji Boa Entrada możemy napotkać na taki opis reprezentantów kultury wyzwoleńców: 


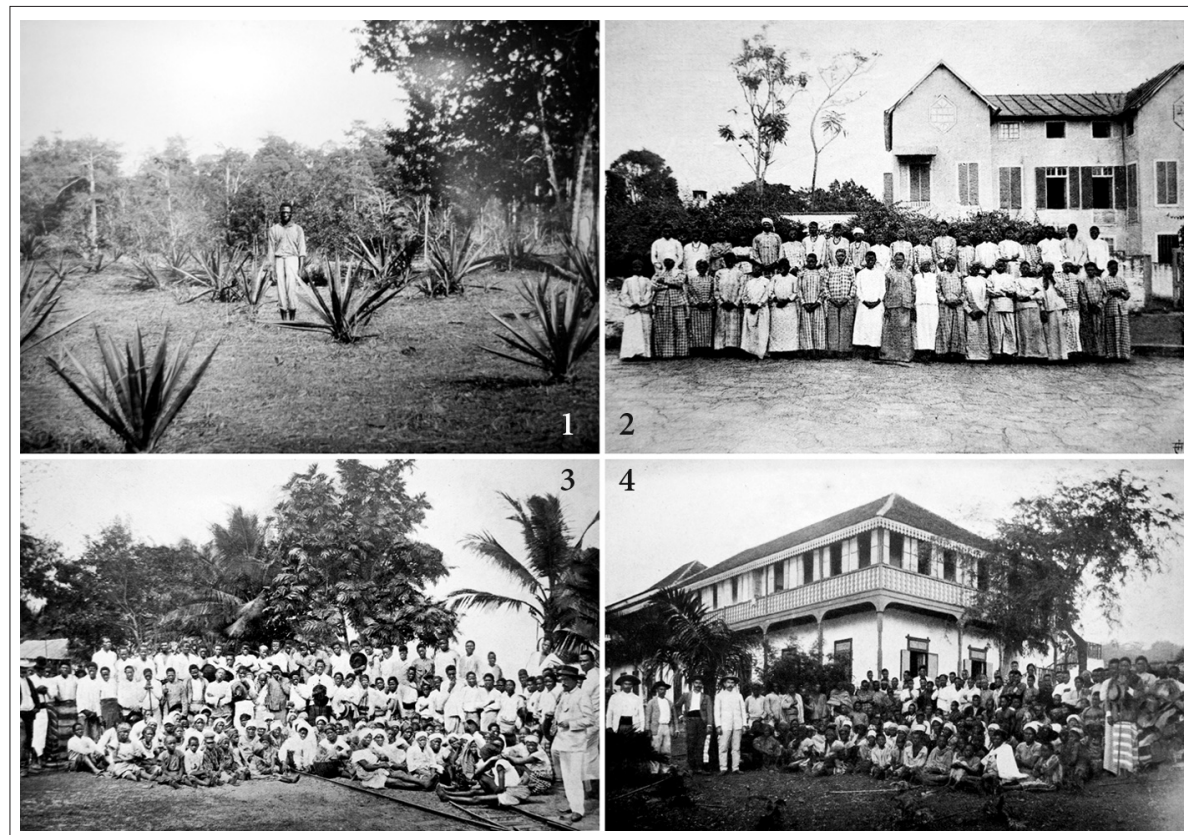

ZDJĘCIE 1. Robotnik kontraktowy podpis pod zdjęciem głosi: „Pole agawy meksykańskiej po trzech i pół roku uprawy”. źróDŁo: (Monteiro de Mendonça, 1907, s. 113). Zdjęcie 2. Pracownicy przed budynkiem głównym plantacji Rio do Ouro. źRóDŁo: Arquivo Histórico, São Tomé. zDJĘCIE 3. Robotnicy kontraktowi z dystryktu Santo Antonio. źróDŁo: Arquivo Histórico, São Tomé. zDJĘCIE 4. Robotnicy kontraktowi i biali nadzorcy. Podpis pod zdjęciem głosi: „Personel posiadłości przed biurem Administracji w dniu wypłaty”. źRóDŁo: Arquivo Histórico, São Tomé.

Pewnego kwietniowego poranka w 1901 roku William Cadbury, zasiadłszy przy swoim biurku, czytał prospekt pewnej Saotomejskiej plantacji. Prospektowi towarzyszyła oferta zakupu plantacji zwanej Traz-os-Montes położonej na wyspie Świętego Tomasza. Posiadłość składała się z 6175 akrów, budynków, maszyn, narzędzi i pojazdów, wymienionych na liście na równi $\mathrm{z}$ dwoma pozycjami, które przykuły uwagę Cadbury'ego - bydło o wartości 420 funtów i 200 czarnych robotników o wartości 3555 funtów. Oferowanie robotników na sprzedaż na równi $\mathrm{z}$ bydłem i maszynami wywołało $\mathrm{w}$ nim podejrzenia, że warunki pracy na wyspie Świętego Tomasza dalekie są od idealnych (Higgs, 2012, s. 9).

Forro to pasożyt posiadłości, żyje z tego co ukradnie innemu, i zaopatruje rączki [ang. the hands - przyp. autor] w brandy, wymieniając ją za kakao, kawę, banany, a co gorsze, za racje [żywnościowe - przyp. autor], które rączki dostają od chlebodawcy na własne wyżywienie; robotnicy oddadzą wszystko co mają, a nawet co ukradną, byle mieć brandy. Boa Entrada otoczona jest przez forros, bezwzględną armię pasożytów pasących się na niej, w zamian zmieniających robotników w anemików i pijaków (Monteiro de Mendonça, 1907, s. 43-44). 
Koniecznie należy podkreślić, iż powyższy passus pojawił się w monografii mającej dać odpór oskarżeniom systemu pracy w koloniach, formułowanym przez światową opinię publiczną, których najlepszym przykładem jest raport Casementa (1904). W tym przypadku „winą" za zły stan zdrowia i wyżywienia obarczani są właśnie wyzwoleńcy, bo nie chlebodawca. Trzeba też zaznaczyć, że autorem skrajnie rasistowskiego opisu przedstawicieli kultury wyzwoleńców i ich rzekomego negatywnego wpływu na robotników kontraktowych plantacji jest niejaki José Antonio Salvado Matta, piastujący funkcję lekarza w plantacji Boa Entrada. Trzecie objaśnienie, jakie muszę tu poczynić dotyczy określenia "rączki”, które pochodzi z portugalskiego mão de obra, co oznacza siłę roboczą, a w dosłownym tłumaczeniu "ręce do pracy”. Pojęcie w takim brzmieniu stanowi wyraz wizji świata portugalskich kolonów, w którym Saotomejczycy zredukowani są do swojej przydatności w procesie produkcji i akumulacji kapitału. A przydatność ta zmniejszana jest - jak przedstawiają to autorzy reprezentujący rasistowski reżim kolonialny - z winy samych Saotomejczyków, pośród których występuje wysoki wskaźnik śmiertelności, pomimo że - zdaniem cytowanego już lekarza - zrobiono wiele, żeby ów wskaźnik obniżyć, zapewniając „pierwszej klasy mieszkania”, czy „więcej niż wystarczające pożywienie” oraz opiekę medyczną nawet dla pacjentów, których „uskarżania się są jawną symulacją”" (Monteiro de Mendonça, 1907, s. 43). Przerażająca konsekwencja, która wynika z takiego postawienia sprawy wskaźnika śmiertelności jest taka, że portugalski lekarz obwinia saotomejskich robotników kontraktowych za to, że szybko umierają. Wymienia on dwie okoliczności - alkoholizm i geofagię:

\footnotetext{
Innym występkiem czarnych robotników, głęboko zakorzenionym i nie mniej szkodliwym niż alkoholizm, jest zwyczaj jedzenia brudu. Pośród Europejczyków jest to zawsze symptom jakiegoś schorzenia lub stanu anormalnego (np. ciąży). Jednak nie u czarnych. Widziałem już krzepkich Afrykańczyków z wigorem bez jakiegokolwiek najlżejszego nawet symptomu anemii lub innej choroby, którzy z powodu zwykłej zachłanności i łakomstwa, (...), żrą ziemię (s. 44).
}

W następnej linijce portugalski lekarz dodaje jeszcze, że są i tacy, którzy „jedzą brud, aby trafić do szpitala”, „gdzie przyjęci są z wygodami i nie mają pracy" (s. 44-45). Pisząc Foucaultem, złe podmioty kierowane są jakąś dziwną wewnętrzną siłą, mając inklinację do zbrodni, występku czy oporu wobec pracy, co jednak nie wyklucza amelioracji. José de Almada Negreiros (1895, s. 11-12) we wstępie do swojej książki Etnograficzna historia Wyspy Św. Tomasza deklaruje, że „nie wierzy w całkowitą antropologiczną niższość czarnych” i że „nie są oni skazani na wieczną ignorancję i podporządkowanie się podłym środkom", postulując dalej edukację religijną, zamiast traktowania Sao- 


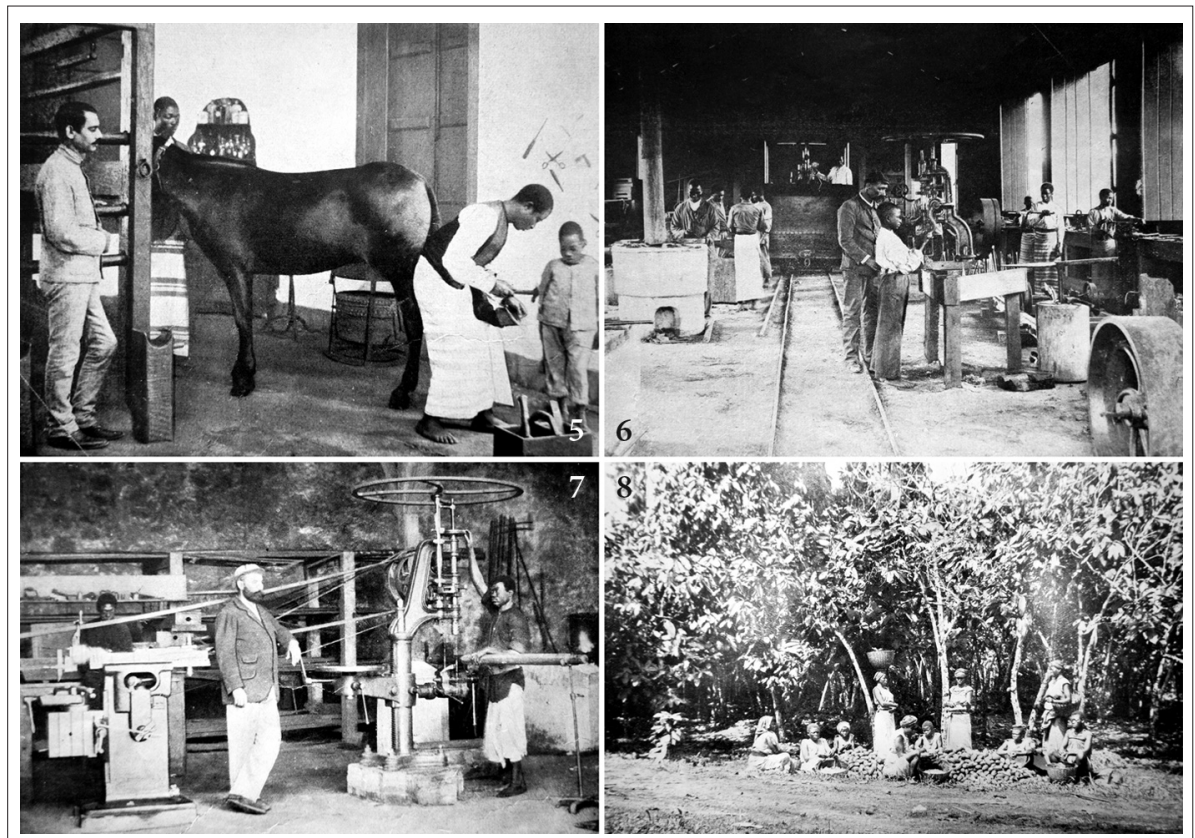

ZDJĘCIE 5. Trzech Saotomejczyków i biały nadzorca. Podpis pod zdjęciem głosi: „Warsztat kowalski - Agua-Izé”. źródŁo: Arquivo Histórico, São Tomé. zDJĘCIE 6. Robotnicy w warsztacie. źróDŁo: Arquivo Histórico, São Tomé. zDJĘCIE 7. Robotnicy ibiały nadzorca w warsztacie kowalsko-ślusarskim. źróDŁo: Arquivo Histórico, São Tomé. zDJĘCIE 8. Saotomejki rozłupujące owoce kakaowca. ŹróDŁo: Arquivo Histórico, São Tomé.

(...) zasadniczo ciało jest blokowane relacjami władzy i dominacji jako siła produkcyjna, ale sprowadzenie go do siły roboczej jest możliwe nie wcześniej, nim zostanie włączone w system ujarzmienia; (...) (Foucault, 2009, s. 27)

tomejczyków jak niewolników. Choć stanowisko Almady Negreirosa jest bardziej humanitarne w swym wyrazie niż stanowisko prezentowane przez lekarza z plantacji Boa Entrada, to w świetle koncepcji Foucaulta jest to pozorna humanizacja, gdyż zniesieniu kaźni czy zniesieniu niewolnictwa (z całym związanym z nim festiwalem przemocy) nie przyświecają intencje poprawy ludzkiego bytu, lecz zmiana ekonomii karania, zmierzająca do ujarzmiania podmiotu środkami coraz bardziej subtelnymi, którymi dysponuje pedagogika czy to pod postacią edukacji religijnej, czy jakiejkolwiek innej. Jak pisze Foucault o wychowaniu w więzieniu:

Ta jakże pożyteczna pedagogika przywróci leniwemu osobnikowi upodobanie do pracy, siłą włączy go w układ interesów, gdzie praca będzie bardziej opłacalna 
niż bezczynność, utworzy wokół niego małą, zamkniętą społeczność, sztuczną i przymusową, gdzie będzie jasno czytelna maksyma: bez pracy nie ma kołaczy (2009).

Foucault wprawdzie odnosi się do obowiązku pracy w więzieniu, który ma zrekonstruować postawę homo oeconomicus w „leniwym osobniku”, ale taka perspektywa zbliżona jest do postawy kolonów wobec Afrykanów, jak przedstawia to Henrique José Monteiro de Mendonça (1907), powołując się na biskupa Kongo Francuskiego, który

bronił przymusowej pracy czarnych, utrzymując, że winno to być narzucenie zdecydowane, ale roztropne, dodając, że spożytkowanie pracy ludności rdzennej w Afryce, dalekie od niewolnictwa, stanowi realizację państwa socjalnego znacznie bardziej korzystną niż ta [z którą mają do czynienia - przyp. autor] biali robotnicy w metropoliach, prawdziwi niewolnicy jarzma podatków, służby wojskowej i krytycznego położenia robotników rolnych. Czarni, jak dodaje przesławny prałat, nie mając żadnych potrzeb, żyjąc teraźniejszym dniem bez troski o jutro, nie będą pracować, chyba że zostaną zmuszeni do tego, ani też nie ucywilizują samych siebie, chyba że wbrew ich woli (s. 13).

Oto koncepcja, jak określa to Monteiro de Mendonça (1907, s. 12), dobrowolnej pracy przymusowej (ang. forced but free labour), która w koloniach stanowi przejście od systemu niewolniczego do nowej organizacji pracy, pracy ciągle przymusowej, ale umożliwiającej dawnemu niewolnikowi wybór zajęcia - jak ma to miejsce do dziś w całym świecie późnego kapitalizmu, który akurat w tym zakresie się nie zmienił. Po drugie, wyraźna jest tu strategia komunikacyjna, zmierzająca do przedstawienia warunków pracy w portugalskich koloniach w jak najlepszym świetle. Warunki pracy i życia kontraktowych robotników przymusowych przedstawione są jako lepsze niż robotników europejskich. José Dionísio Conde de Sousa e Faro (1908, s. 105-106) w monografii, która jest bezpośrednią odpowiedzią na raport Burtta pisze z oburzeniem, iż określenie "niewolnicze kakao” to atak „Pana Cudbury” na „uzasadnione interesy” plantatorów portugalskich, a sami robotnicy rolni z STP są relatywnie bardziej szczęśliwi od robotników europejskich, skąd wysnuwa wniosek, że STP pod portugalskim panowaniem to „raj czarnych”. Połajanka między portugalskimi plantatorami i brytyjskimi fabrykantami, a właściwie pomiędzy portugalskimi i brytyjskimi kapitalistami ujawnia hipokryzję obu stron - hipokryzję, która wynika z konfliktu interesów, gdyż „Cudbury Brothers” sprowadzają 55\% potrzebnego kakao właśnie z STP, a William Cudbury nosi się z zamiarem wykupu portugalskich plantacji (Higgs, 2012, s. 9). Co ważniejsze, hipokryzję, która polega na tym, że obie strony tego medialnego - jak na owe czasy - sporu bardziej przejmują się 
losami „dobrowolnych pracowników przymusowych” swojego oponenta niż własnych. W obu przypadkach troska o humanizację pracy i humanitarne traktowanie pracowników jest wysoce wątpliwa w świetle Foucaultowskiej (2009, s. 133) koncepcji relacji między przydatnością i podatnością. Pisząc Foucaultem:

To polityczne blokowanie ciała wiąże się na zasadzie skomplikowanych i wzajemnych zależności z jego wykorzystaniem ekonomicznym: zasadniczo ciało jest blokowane relacjami władzy i dominacji jako siła produkcyjna, ale sprowadzenie go do siły roboczej jest możliwe nie wcześniej, nim zostanie włączone w system ujarzmienia (...) jego siła staje się pożyteczna dopiero wówczas, kiedy będzie ciałem produktywnym i ujarzmionym zarazem (s. 27).

A w innym miejscu Nadzorować i karać:

Metody te, pozwalające na drobiazgową kontrolę czynności ciała, zapewniające ciągłe ujarzmianie jego sił i narzucające mu relację „podatność-przydatność, można nazwać dyscyplinami (s. 133).

Konkludując, odejście od kaźni czy odejście od niewolnictwa (ewentualnie porządku feudalnego) nie może po prostu być interpretowane jako forma humanizacji, na przekór temu, co utrzymują warstwy uprzywilejowane, postrzegając relacje między Europejczykami i Afrykanami w kategoriach „perfekcyjnej harmonii” między europejskimi rządcami (port. pessoal dirigente europeu - przyp. autor) a rdzennymi robotnikami (port. pessoal indigena trabalhador - przyp. autor) (Sousa e Faro, 1908, s. 104). Samo zaś zniesienie niewolnictwa zostało dokonane - zdaniem Sousa e Faro (s. 199-200) - z pobudek humanitarnych i filantropijnych, czego Cadbury nie jest świadom, gdyż „nie zna historii handlu i terytoriów zamorskich Portugalii”. Kulminacyjnym - w swej hipokryzji - momentem filipiki przeciwko raportowi Burtta jest zarzut niedoceniania „dzielności” robotników rolnych z STP i tego, że oni całe swe „serce wkładają w pracę” (s. 200).

Moment zniesienia niewolnictwa na STP jest momentem narodzin wiedzy o tym, jak sprawić, by ciało było bardziej wydajne, posłuszne, podporządkowane i użyteczne. Saotomejczyk nie jest już traktowany na równi z inwentarzem rolnym - choć bezpośrednią przyczyną powstania raportu Burtta była oferta sprzedaży plantacji Traz-os-Montes z roku 1901, która zawierała pozycję „200 czarnych robotników” obok zwierząt hodowlanych, zabudowań, narzędzi i maszyn (Higgs, 2012, s. 9). Robotnik rolny wpada w sieć zależności, na którą składa się całkowita kontrola plantatorów nad polityką mieszkaniową, zdrowotną, wymiarem sprawiedliwości i handlem detalicznym. Wszystkie, przypisywane przez kolonów sobie samym, faktyczne i pozorne zdobycze cywi- 
lizacyjne są ostatecznie finansowane z quasi-niewolniczej pracy przymusowych robotników kontraktowych. Wyłom w tej konstrukcji społecznej stanowi wspólnota wyzwoleńców, która nie dość, że łamie monopol plantatorów w dostarczaniu dóbr konsumpcyjnych robotnikom rolnym, to dodatkowo jeszcze swoją praktyką życia dowodzi, że można żyć poza plantacjami, wywołując długotrwały proces odpływu pracowników z portugalskich plantacji. Dla portugalskich kolonów jest to moment, o którym Foucault pisze tak:

Kształtuje się wówczas polityka przymusu, który polega na pracy nad ciałem, przemyślanej manipulacji jego częściami, ruchami, czynnościami. Ciało ludzkie dostaje się w tryby maszynerii władzy, która dokonuje rewizji, rozbiera na części i na powrót składa. Oto chwila narodzin „anatomii politycznej” będącej zarazem swoistą „mechaniką władzy”: określa ona, w jaki sposób można wpływać na ciała innych - nie tylko żeby wykonały to, czego się od nich chce, ale żeby działały tak, jak się chce, za pomocą z góry określonych technik, z określoną szybkością i wydajnością. Dyscyplina wytwarza tedy ciała podporządkowane i wyćwiczone, ciała „podatne”. Dyscyplina wzmaga siły ciała (w ekonomicznym sensie użyteczności) i zarazem osłabia te siły (w politycznym sensie posłuszeństwa). (...) Można powiedzieć, że jeśli wyzysk ekonomiczny oddziela pracę od produktu pracy, przymus dyscyplinarny czyni ciało miejscem koniecznego związku pomiędzy jego wzmożoną sprawnością a wzrastającą dominacją (2009, s. 133-134).

Aby wymusić posłuszeństwo i europejscy fabrykanci, i kolonialni plantatorzy wprowadzają mechanizm panoptyczny do zasad organizacji pracy - „Inspekcja działa bez przerwy. Wszędzie baczne spojrzenie” - pisze Foucault (2009, s. 191). Benthamowski panopticon stanowi „architektoniczną figurę" urządzenia dyscyplinarnego (s. 195) i jak zachwala sam Jeremy Bentham:

Nie ważne jak różne, albo wręcz sprzeczne cele: czy będzie to karanie niepoprawnych, pilnowanie szalonych, reformowanie zdeprawowanych, zamknięcie podejrzanych, zatrudnianie gnuśnych, zabezpieczenie bezradnych, leczenie chorych, instruowanie chętnych w dowolnej gałęzi przemysłu lub szkolenie rasy wchodzącej po ścieżce edukacji: jednym słowem, czy będzie zastosowane w więzieniach (...), czy w domach poprawczych, czy warsztatach, czy manufakturach, czy domach dla obłąkanych, czy szpitalach, czy też szkołach. To oczywiste, że we wszystkich tych przypadkach, im dokładniej osoby są poddane inspekcji, im bardziej są pod okiem osoby, która ich obserwuje, tym bardziej wzorowo osiągany będzie cel X określonej placówki (1838, s. 40).

Architektoniczne rozwiązania tego typu, obejmujące ścisłą parcelację przestrzenną, kontrolowanie przepływu ludzi, wzbudzenie przeświadczenia o widzialności - rozwiązania, które mają zautomatyzować i zdezindywidualizować władzę i które mają poprawić wydajność (Foucault, 2009, s. 191-197) zastosowane zostały na portugalskich plantacjach na STP. Logika tego rodzaju doro- 


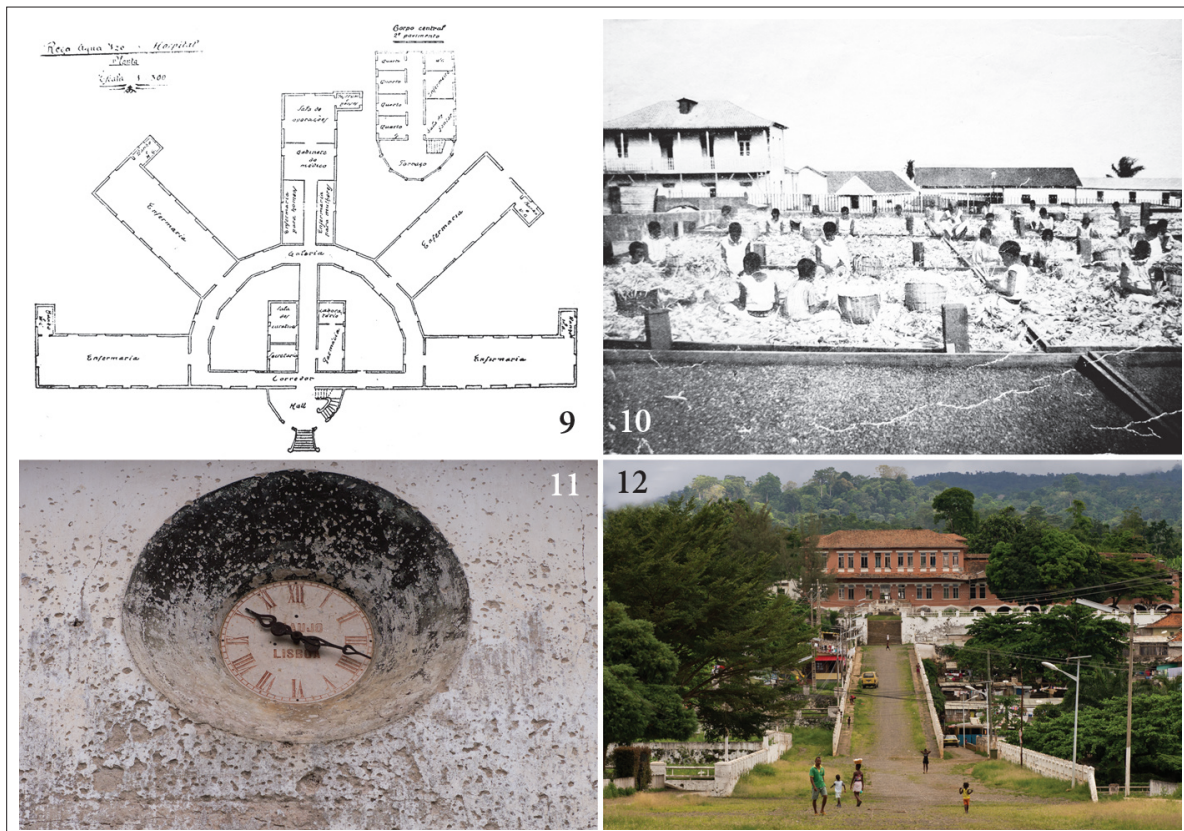

ZDJĘCIE 9. Plan szpitala w plantacji Agua-Izé. źRóDŁo: Arquivo Histórico, São Tomé. ZDJĘCIE 10. Kobiety przy pracy. źRóDŁo: Arquivo Histórico, São Tomé. ZDJĘCIE 11. Zegar w plantacji Monte Café. źRóDŁo: zbiory własne. zDJĘCIE 12. Widok z budynku głównego plantacji Rio de Ouro (obecnie Agostinho Neto) na szpital i czworaki. źRóDŁO: zbiory własne.

Chodzi tu, w pewnym sensie, o rodzaj mikrofizyki władzy, którą wprawiają w ruch organy i instytucje państwowe, ale jej pole ważności rozpościera się niejako pomiędzy tymi wielkimi maszyneriami a samymi ciałami $\mathrm{z}$ ich materialnością i siłą. (Foucault, 2009, s. 28)

zumiana jest w monografii Monteiro de Mendonçy (1907, s. 18-19), gdzie w jednym zdaniu pisze on, iż ludność rdzenna „czuje wstręt do stałej i zdyscyplinowanej pracy”, bo woli "grabić majątek, aby się utrzymać”, by w następnym przedstawić architektoniczne rozwiązania z plantacji Boa Entrada i Rio de Ouro, w skład których wchodzą szerokie ulice o symetrycznym rozkładzie, oświetlenie elektryczne, ceglane lub betonowe czworaki (port. sanzallas - przyp. autor). W tym miejscu wróciliśmy do punktu wyjścia: złe z natury podmioty o podatnych ciałach poddać należy procesom amelioracji, tak by ich ciała stały się przydatne, aby stały się siłą roboczą. Proces amelioracji umożliwiony jest przez rozwiązania panoptyczne. 


\section{Freirego Foucaultem: akcja powszechnej alfabetyzacji w perspektywie Foucaultowskiej}

Badacze z kręgu luzofońskiego uznają Freirowskie doświadczenia w dekolonizującej się Afryce za kluczowe wydarzenie w epopei edukacyjnej tego brazylijskiego pedagoga i filozofa wychowania. Przyjęty przez Freirego indukcyjny schemat konstruowania teorii edukacji polegał na tym, iż jego teoria pedagogiki emancypacyjnej rozwijała się w rytmie kolejnych przedsięwzięć, w które angażował się Freire. Nie inaczej stało się z doświadczeniem afrykańskim Freirego, w trakcie którego uczestniczył on w akcjach, które okazały się spektakularnym sukcesem - jak miało to miejsce na STP. Podobnie kształcącym dla Freirego przedsięwzięciem musiała być nieudana akcja alfabetyzacyjna w Gwinei-Bissau. Co jeszcze ciekawsze, nie tylko z perspektywy polskiej pedagogiki, to że na etapie afrykańskim Freire był pod silnym wpływem teorii pedagogiki materialistycznej Bogdana Suchodolskiego (Stańczyk, 2018a).

Punkt wyjścia dla reform młodych w swej niepodległości państw Afryki luzofońskiej był trudny. Wysoki poziom analfabetyzmu spowodowany był celowymi działaniami faszystowskiego i rasistowskiego reżimu, a dostęp do edukacji pośród Afrykanów miała jedynie urzędnicza „klasa średnia”. W związku z tym wskaźnik skolaryzacji netto na poziomie podstawowym wynosił mniej niż 20\% kohorty (dzieci i młodzieży w wieku szkolnym) (Torres, 1996, s. 128-131). W ciągu tylko czterech pierwszych lat funkcjonowania programu powszechnej alfabetyzacji wskaźnik analfabetyzmu obniżył się o 30 punktów procentowych (Gerhardt, 1996, s. 165). Badacze skupieni wokół Instituto Paulo Freire podkreślają, że brazylijski edukator zafascynowany był możliwościami, jakie daje „eksperyment socjalistyczny” z jego ambitnymi reformami społecznymi, w tym przede wszystkim z projektami akcji alfabetyzacyjnych, które odbywały się na skalę całych państw i nie w oderwaniu od przekształcania materialnych warunków życia i pracy (Torres, 1996, 134-135). Wyróżniłbym tutaj trzy kluczowe cechy edukacji ludowej zmierzającej do upowszechnienia umiejętności czytania i pisania, i będzie to - po pierwsze - uznanie warstw ludowych (uciśnionych) za zdolne do samodzielnego dokonywania przekształceń społecznych, a także uznanie wartości i witalności kultury ludowej (Brandão, Assumpção, 2009). Po drugie, chodzi o zmianę epistemologiczną proponowaną przez wyrosłą z praktyki Freirowskiej filozofię edukacji, która polega na przejściu od konserwatywnego („bankowego”) myślenia o pełni wiedzy do myślenia o poznawalnym przedmiocie (Freire, 1979). Natomiast z tym przejściem epistemologicznym wiąże się ustanowienie procesu pracy (tak materialnej, jak i intelektualnej) jako pryncypium pedagogicznego (Romão, Gadotti, 2012, s. 60). To właśnie przekształcanie świata za pomocą 
pracy stanowi źródło poznania świata przyrodniczego i społecznego, a także siebie samego, a kluczem do emancypacji jest „reorientacja społecznego użycia sił produkcyjnych" (Freire, 1978, s. 8), czyli zerwanie z kolonialnymi nierównościami, kolonialną organizacją pracy, a także zwrócenie się społeczeństwa ku rozwiązywaniu żywotnych dlań problemów społecznych (wyżywienia, ochrony zdrowia, mieszkalnictwa itd.).

Lista słów generatywnych (w podręczniku do alfabetyzacji) oraz lista tematów generatywnych (w serii podręczników wykorzystanych w procesie post-alfabetyzacji) powstawała $\mathrm{w}$ trakcie badań i pracy $\mathrm{w}$ terenie, $\mathrm{w}$ których uczestniczyli na równi alfabetyzowani, edukatorzy z STP i spoza STP - jak choćby sam Freire. Podejście do tworzenia programu dobrze ilustruje historia z miejscowości Monte Mário, w której Freire pracował jako nauczyciel (Freire, 1978, s. 54; Stańczyk, 2018a, s. 21-22). Cykl podręczników pod tytułem Walka trwa. Zeszyty kultury ludowej [port. A Luta Continua. Cadernos de Cultura Popular - przyp. autor] składał się z podręcznika do alfabetyzacji początkowej (zeszyt 1.) uzupełnionego przez Zeszyt ćwiczeń oraz zeszyty do post-alfabetyzacji (zeszyty od 2. do 6.). Opis i interpretacja zawartości zeszytu 1. i 2. może być już znana czytelnikowi (Stańczyk, 2017, 2018a, 2018b). Ostatecznie, reformy społeczne w ogóle, a w szczególności akcja alfabetyzacyjna połączona z praktycznymi działaniami, zorientowanymi na rozwiązywanie praktycznych problemów społeczeństwa, przyniosły długotrwałe rezultaty w postaci: niskich wskaźników rozwarstwienia społecznego (które bardziej przypominają specyfikę państw europejskich niż afrykańskich); zapewnienia powszechnego dostępu do edukacji (co jednak nie oznacza, że system jest całkowicie wydolny); zapewnienia dostępu do służby zdrowia i skuteczne prowadzenie polityki prozdrowotnej (czego najlepszym przykładem jest całkowite zwalczenie malarii); wysokiej stabilności politycznej (od uzyskania niepodległości były dwie nieskuteczne próby przewrotu, ale obyło się bez ofiar). Oczywiście STP przeżywa rozmaite problemy, choćby z tego powodu, że otwiera drugą ćwiartkę państw pod względem PKB per capita liczonego parytetem siły nabywczej, skąd wynika brak kapitału inwestycyjnego i brak kapitału obrotowego, co skutkuje tym, że stolica São Tomé w ostatnim czasie odnotowuje braki w dostawach prądu, niemniej bilans reform jest wyraźnie dodatni, a w porównaniu nawet do bogatszych krajów regionu (jak choćby RPA) STP może uchodzić za raj zrównoważonego rozwoju. Co jednak, gdy przyjrzymy się reformom z okresu młodej niepodległości STP w perspektywie Foucaultowskiej? Odpowiedź może okazać się druzgocząca dla zwolenników pedagogiki emancypacyjnej Freirego, do których zaliczam także siebie. Spróbuję jednak wykonać takie ćwiczenie $\mathrm{z}$ archeologii wiedzy, sięgając do materiałów 
z cyklu Zeszytów kultury ludowej. Nie będzie to jednak analiza całości ich treści, lecz zwrócenie uwagi na - w mojej opinii - kluczowe wyimki - kluczowe w tym sensie, że przesądzające możliwą interpretację dokonaną w duchu Foucaultowskim.

Poniższy tekst jest trzecią częścią cyklu czytanek pod tytułem „Rekonstrukcja narodowa”, zawartych w 2. Zeszycie kultury ludowej:

Zwiększona produkcja na plantacjach i w fabrykach, wytężona praca w sektorze publicznym, jedność, dyscyplina, praca i czujność, aby stworzyć nowe społeczeństwo, wszystko to wymaga istnienia rewolucyjnej awangardy. Lud zdezorganizowany, bez jedności, bez dyscypliny, nie zwycięży. Lud wymaga rewolucyjnej awangardy. W jedności awangardy i Ludu, awangarda też jest Ludem.

MLSTP jest awangardą rewolucyjną naszego Ludu.

Niech żyje lud zorganizowany i silny!

Niech żyje MLSTP! (Ministério de Educação Nacional e Desporto, 1978, s. 11).

$\mathrm{Z}$ jednej strony od razu nasuwa się wspomnienie retoryki z okresu sprzed 1989 roku, ale co ważniejsze, to że koncepcja Foucaulta doskonale pasuje do krytyki tamtego okresu w krajach europejskich, w których panowały rządy tzw. demokracji ludowej. Mamy tu do czynienia przede wszystkim ze zbitką „dyscyplina pracy”, która w warunkach zdehumanizowanego i dehumanizującego porządku polityczno-gospodarczego sprowadza się do technik zmieniających jednostkę w siłę roboczą. Drugi ciekawy fenomen językowy, który wyłania się z przedstawionej czytanki to złożenie czujności i jedności - jedność w połączeniu z czujnością jest synonimem paranoi państwa policyjnego, będącego siermiężną wersją społeczeństw, w których agenci i tajni współpracownicy zastąpieni zostali permanentną inwigilacją opartą na nowych technologiach. Z punktu widzenia analiz dokonanych tu wcześniej ważniejsze wydaje się jednak zagadnienie dyscypliny pracy, które obrazowane są na zdjęciach (nr 13-16).

Zdjęcia te pochodzą z 1. Zeszytu kultury ludowej i zostały tak dobrane, by przedstawiały Saotomejczyków i Saotomejki przy pracy i w czasie wolnym. Jeżeli język jest systemem opozycji, to dotyczy to także języka wizualnego. Musimy tu sobie uzmysłowić, że znaczące jest nie tylko to, co i jak jest przedstawiane, ale także co i dlaczego nie jest przedstawiane. Porównując zdjęcia zawarte w monografiach z początku XX wieku i te zawarte we Freirowskim elementarzu łatwo zauważyć, że nie istniało coś takiego jak zjawisko czasu wolnego Saotomejczyków. Wprawdzie w przewodnikach turystycznych $\mathrm{z}$ drugiej połowy lat 50. i z lat 60. pojawiają się obrazy przedstawiające tańce ludowe wykonywane dla turystów, lecz przedstawienia te noszą cechy egzo- 


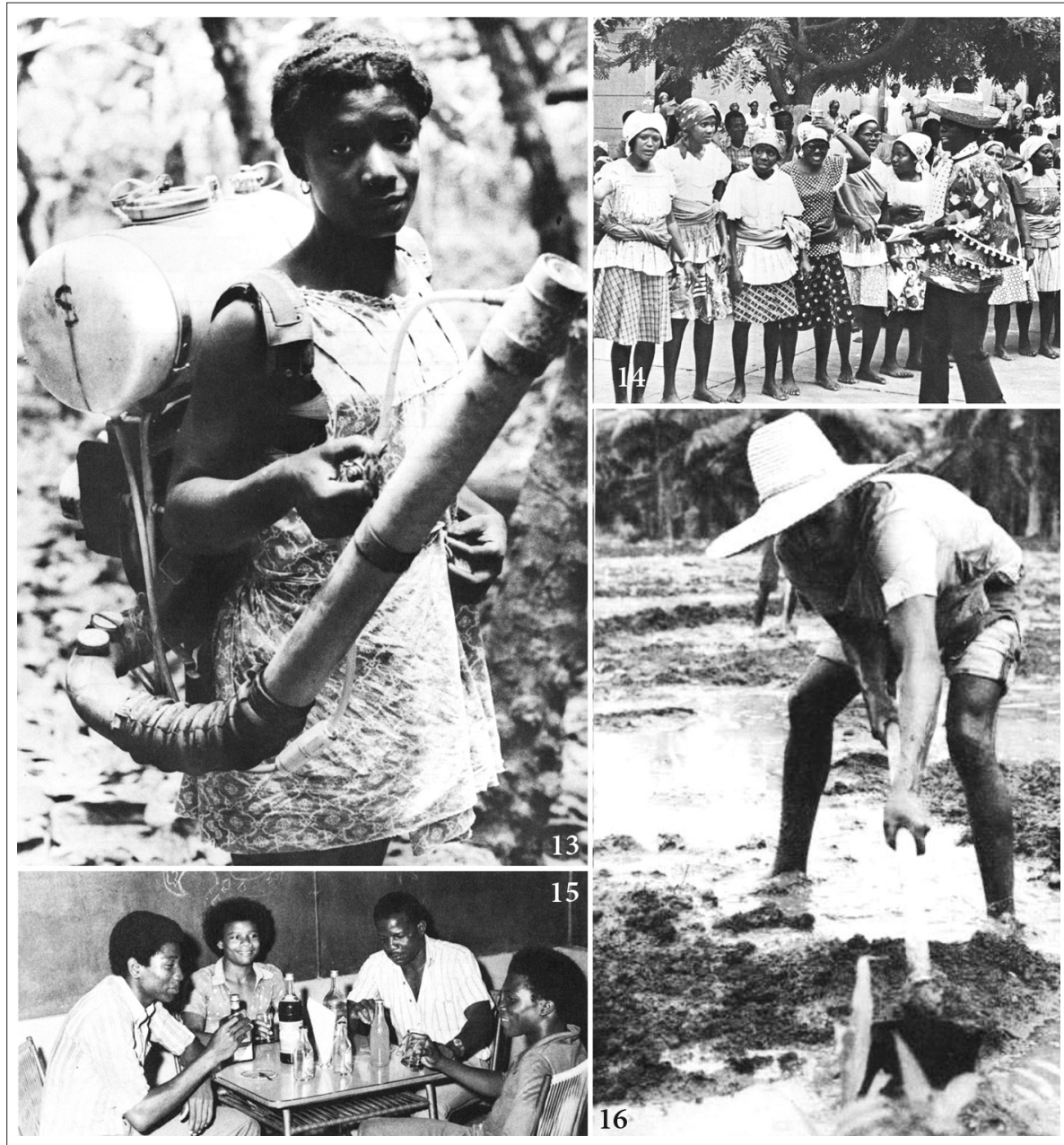

ZDJĘCIE 13. Saotomejka z pulweryzatorem. ZDJĘCIE 14. Saotomejki i Saotomejczycy podczas święta ludowego. zDJĘCIE 15. Saotomejczycy w trakcie spotkania towarzyskiego: słowo generatywne „wino”. zDJĘCIE 16. Mężczyzna przy pracy na roli: słowo generatywne „motyka”. źródŁo: Ministério de Educação Nacional e Desporto, 1978.

Jedno z Kół Kultury już istnieje na plaży w Monte Mário. Alfabetyzowani z tego Koła dają pewność, że cisza już nie jest możliwa. Tworzone są obiektywne warunki, dzięki którym, poprzez praktykę i myślenie, w Kołach Kultury ustanawia się permanentny dialog (...). (Pinto da Costa za: Freire, 1978, s. 6)

tyzacji. To, co w sposób znaczący różnicuje omawiane tu teksty, zawierające materiał wizualny, to że za temat produktywny w podstawowej alfabetyzacji może być uznana konsumpcja alkoholu, czyli czynność, którą portugalscy koloni traktowali jako najpoważniejszy delikt względem produktywności. 
Innym ciekawym fragmentem z cyklu Zeszytów kultury ludowej, a który $\mathrm{z}$ łatwością uruchamia całe pokłady krytyczności koncepcji Foucaulta, jest diagram na temat związku między profilaktyką zdrowia i produktywnością.

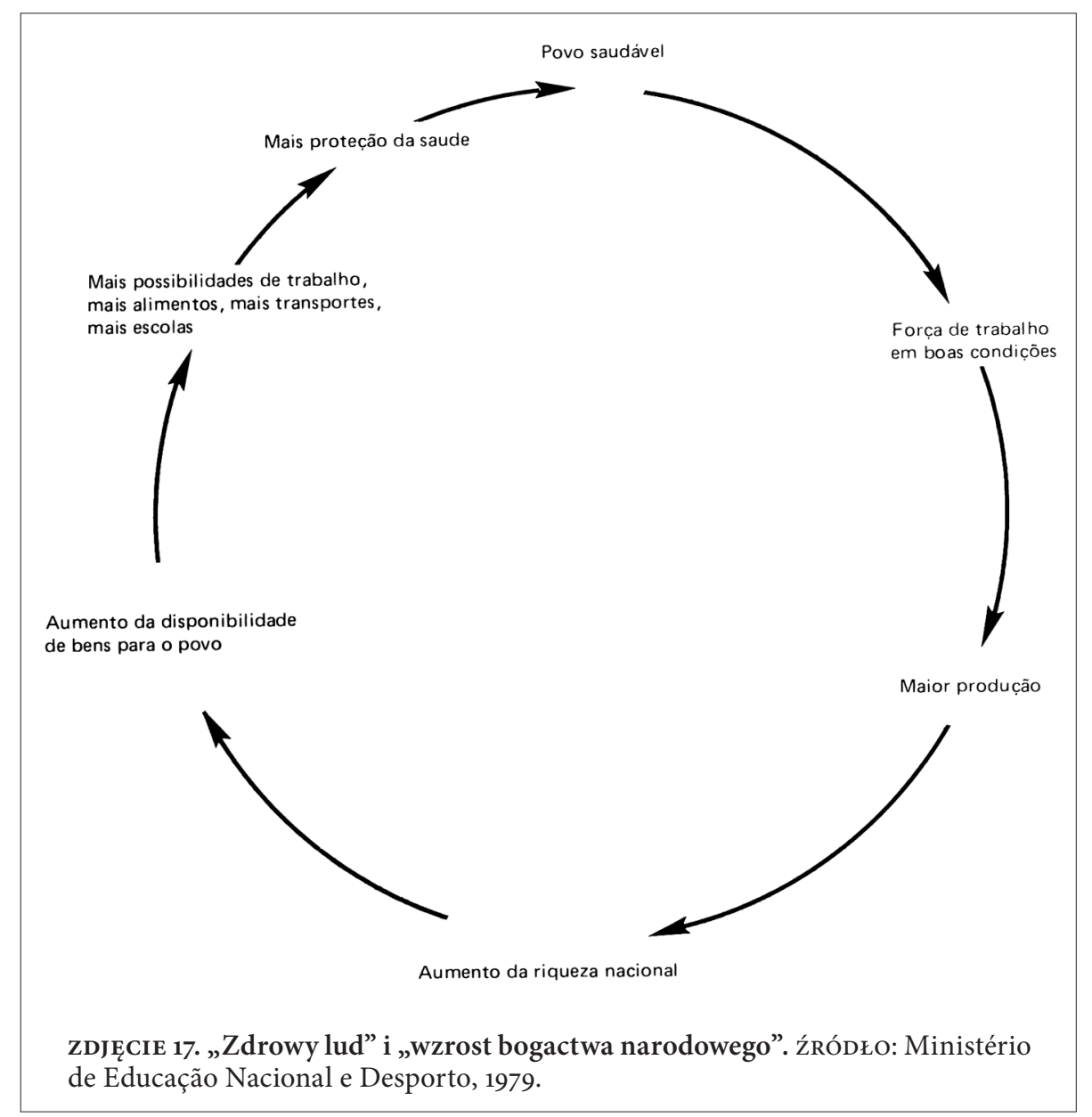

Diagram przedstawia sprzężenie zwrotne między „zdrowym ludem” a „wzrostem bogactwa narodowego". Zaczynając od góry wykresu (od godziny 12) i podążając zgodnie ze wskazówkami zegara mamy przedstawioną taką oto zależność. „Lud zdrowy” oznacza „siłę roboczą w dobrej kondycji”, co przekłada się na „większą produkcję”, a w konsekwencji „zwiększenie bogactwa narodowego”. Z kolei „Zwiększenie bogactwa” oznacza „Zwiększenie dostępności towarów dla ludu”, a to przekłada się na „Zwiększenie możliwości pracy, lepsze wyżywienie, transport i więcej szkół”, co w konsekwen- 
cji prowadzi do „lepszej ochrony zdrowia” i do osiągnięcia stanu „zdrowego ludu". Odrobione ćwiczenia z Foucaulta prowadzą nas do prostej konstatacji, że ów schemat zależności między profilaktyką zdrowia i produktywnością, jako składnik programu post-alfabetyzacji, jest egzemplifikacją ekonomii politycznej ciała, która za swój cel ma ujarzmienie, przekształcenie podmiotu w siłę roboczą. Takie przekształcenie, które umożliwi kontrolowanie ciała i rozdysponowanie go w procesie produkcji. Tu można też zadać pytanie, czy sposób myślenia o zdrowiu po uzyskaniu niepodległości różni się jakościowo od tego reprezentowanego przez lekarza z plantacji Boa Entrada? Pytanie to ma sens z perspektywy Foucaultowskiej, ale nie Freirowskiej, gdzie odpowiedź jest oczywista i brzmi tak.

Warto jednak zauważyć, że choć we Freirowskich podręcznikach brak założenia, iż lud jest zły, bo skłonny do deliktów, a "negatywni bohaterowie" cyklu podręczników mają charakter bezosobowy (jak na przykład „kaszel” lub „komar”), to ciągle saotomejski i Freirowski projekt alfabetyzacji za swą istotę ma proces - pisząc Foucaultem - amelioracji jednostki i społeczeństwa. Można wręcz rzec, że właśnie poprawa czy też naprawa społeczeństwa, uczynienie świata bardziej ludzkim, jest istotą pedagogiki emancypacyjnej, której pryncypium jest praca (Stańczyk, 2018a). Ostatecznie możemy postrzegać treści cyklu Zeszytów kultury ludowej w kategoriach urządzania ludu (Foucault, 2000a, 2010), w którym sposoby sprawowania władzy nad populacją sprowadzają się do tego, by sama jednostka dbała o społecznie skonstruowany stan szczęśliwości, własnej szczęśliwości (200ob), co w tym przykładzie oznacza dbałość o stan zdrowia, a pośrednio dbałość o dobrobyt wspólnoty.

W perspektywie Foucaultowskiej dla jednostki niewiele się zmienia wraz procesem doskonalenia ekonomii władzy, w tym sensie, że jest ta jednostka ciągle tylko ujarzmionym podmiotem, który - nawiązując do Althussera (2006, s. 23) - jest interpelowany przez ideologię: „Hej, ty tam!”. „Hej, ty tam!” - Pracujesz? Uczysz się? Szczepisz się? Łykasz tabletki antymalaryczne? Bierzesz udział $\mathrm{w}$ rekonstrukcji narodowej? Jesteś zdyscyplinowany? Walczysz o nowe społeczeństwo? Walczysz z malarią? Myślisz poprawnie? Jesteś nowym człowiekiem? (Ministério de Educação Nacional e Desporto, 1979; Stańczyk, 2017). W tej perspektywie intelektualnej człowiek pozostaje tylko przydatną siłą roboczą pomimo i na przekór działaniom, które w swych założeniach miały humanizować świat człowieka - czynić bardziej ludzkim świat przyrodniczy i świat społeczny. W perspektywie koncepcji Foucaulta nic się $\mathrm{w}$ tej mierze nie zmienia pomimo i na przekór rzeczywistym i długotrwałym efektom reform społecznych, które przeprowadziły STP od systemu quasi-niewolniczego z okresu faszystowskiej i rasistowskiej dyktatury do niepodle- 
głości, która wiązała się z dekolonizacją i demokratyzacją, która z kolei wiązała się z dowartościowaniem i upodmiotowieniem ludzi. To właśnie podejście do upodmiotowienia Freirego i Foucaulta całkowicie różnicuje ich stosunek do zmiany społecznej. Foucaultowska koncepcja upodmiotowienia to ujarzmienie człowieka, jego uwikłanie w sieć zależności, które powodują, że to, co Freire będzie postrzegał jako proces humanizacji świata, dla Foucaulta będzie jedynie pozorną humanizacją. Przy tym, trzeba tu zauważyć, że w tej mierze - używający pojęcia ujarzmiania - Althusser jednak będzie bliższy Freiremu niż Foucaultowi, gdyż ujarzmianie jest dla niego procesem charakterystycznym dla reprodukcji kapitalizmu.

\section{Zakończenie: o Foucaulcie, Freirem i pedagogice materialistycznej}

Ćwiczenia intelektualne, które możemy wykonać za pomocą koncepcji Foucaulta, z pewnością rozwijają naszą krytyczność, tyle że - na przykładzie akcji alfabetyzacyjnej na STP - jakakolwiek zmiana społeczna, nawet ta, która zmierza ku emancypacji i przynosi trwałą poprawę codziennego ludzkiego życia, może zostać zdezawuowana i zrzucona na karb pozornej humanizacji, której celem będzie bardziej jeszcze subtelna, stąd i bardziej wydajna, forma zamiany człowieka w podporządkowaną siłę roboczą. Z jednej strony, tak faktycznie jest - kapitalizm ma wysoką zdolność do przyswajania zdobyczy społecznych, a humanizacja pracy (poprzez znoszenie alienacji subiektywnej) ma za swój cel zwiększanie produktywności, a za tym zwiększanie alienacji obiektywnej, co znajduje swoje potwierdzenie choćby w rosnącej dysproporcji między pracą i kapitałem (Piketty, 2015). Z drugiej strony, paraliżuje to jakiekolwiek myślenie i działania na rzecz - jakby określili freiryści - uczynienia świata bardziej ludzkim, gdyż każda taka zmiana jest pozorna. Jakby tego było mało, koncepcja Freirego w Foucaultowskiej perspektywie jest tylko jednym „z tych wszystkich” „przegadanych przedsięwzięć, zarówno teoretycznych, jak i praktycznych" (Foucault, 2013, s. 169).

Mój - inspirowany Freirem - pogląd na koncepcje Foucaulta zbliżony jest do krytyki Foucaulta przeprowadzonej przez Mariusza Granosika (2018). Zgodność naszych perspektyw wynika prawdopodobnie także z tego, że Granosik krytykuje Foucaulta z punktu widzenia pracy socjalnej, która u Freirego stanowi integralną część koncepcji edukacji ludowej. Granosik pisze, że:

Mam w miarę silne przekonanie, że koncepcji rządomyślności nie da się podważyć teoretycznie, bo przecież każdą inną teorię można za jej pomocą wytłumaczyć, ani tym bardziej empirycznie, pozostaje tylko ścieżka zaprzeczenia pragmatycznego (wymagająca wykazania małej przydatności praktycznej) (2018, s. 170). 


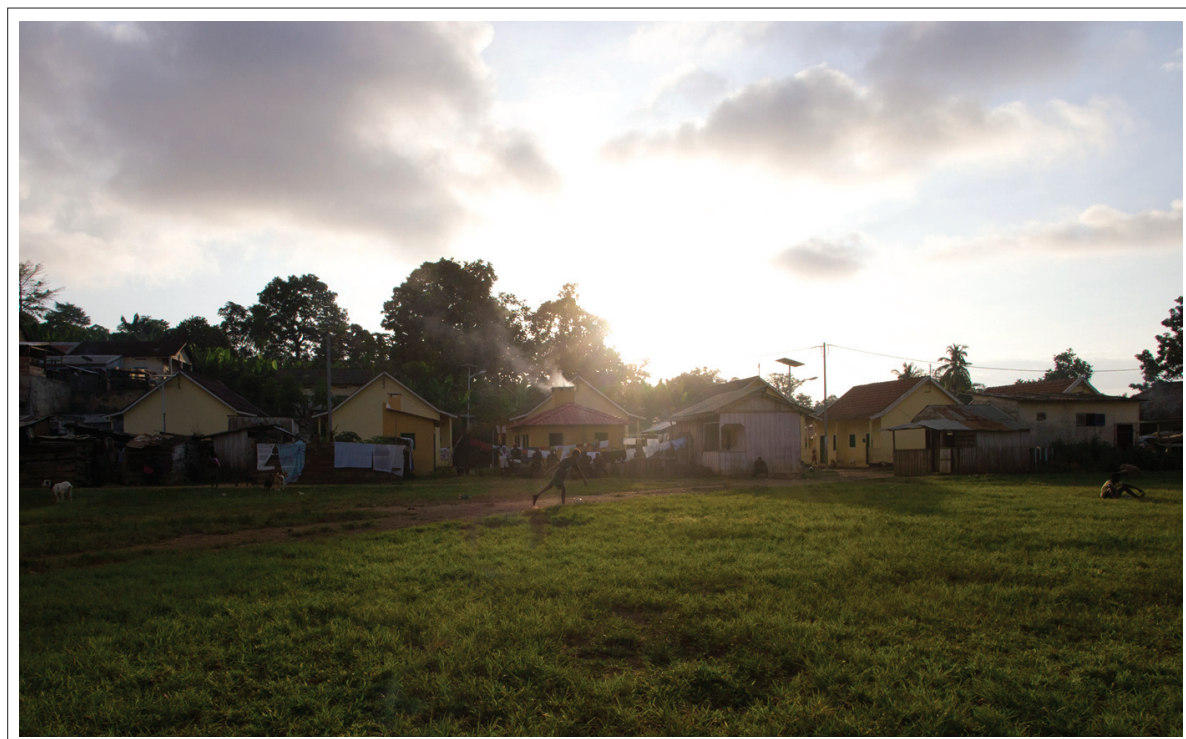

ZDJĘCIE 18. Boa Entrada dziś, widok na dawne czworaki. źróDŁo: zbiory własne.

I dalej:

Intelektualna przygoda z Foucaultem z pewnością trwale oddziałuje na sposób postrzegania rzeczywistości społecznej. Formatuje go krytycznie, ale i podejrzliwie, prowadząc niekiedy do obsesyjnego poszukiwania coraz to bardziej ukrytych i wysublimowanych mechanizmów rządzenia (s. 184).

Postawa intelektualna, która - moim zdaniem - charakteryzuje Foucaulta polega na zwycięstwie „rozumu cynicznego” w rozumieniu Petera Sloterdijka (2008). W takim przypadku tak Freire, jak i oświatowcy, nauczyciele, edukatorzy, streetworkerzy, czy pracownicy społeczni działający na rzecz ludzkiego upełnomocnienia mogą uchodzić za pierwszych naiwnych, bo jakiekolwiek ich działania właściwie zawsze przynoszą odwrotne rezultaty od założonych, prowadząc do coraz to subtelniejszych form dominacji. Choćby i koncepcja Foucaulta była trafna teoretycznie (choć trudno o jej falsyfikację, co stanowi ważny jej mankament metodologiczny), to jest ona pragmatycznie chybiona, gdy tylko spojrzymy nań z perspektywy społecznych nauk stosowanych, jakimi są choćby pedagogika czy praca socjalna. Mówiąc inaczej i operując metaforą - koncepcja Freirego jest instrukcją obsługi społeczeństwa w drodze do emancypacji dowolnej grupy uciśnionych. Jeżeli koncepcja Foucaulta miałaby być instrukcją obsługi społeczeństwa, to jedynie dla uciskających. 


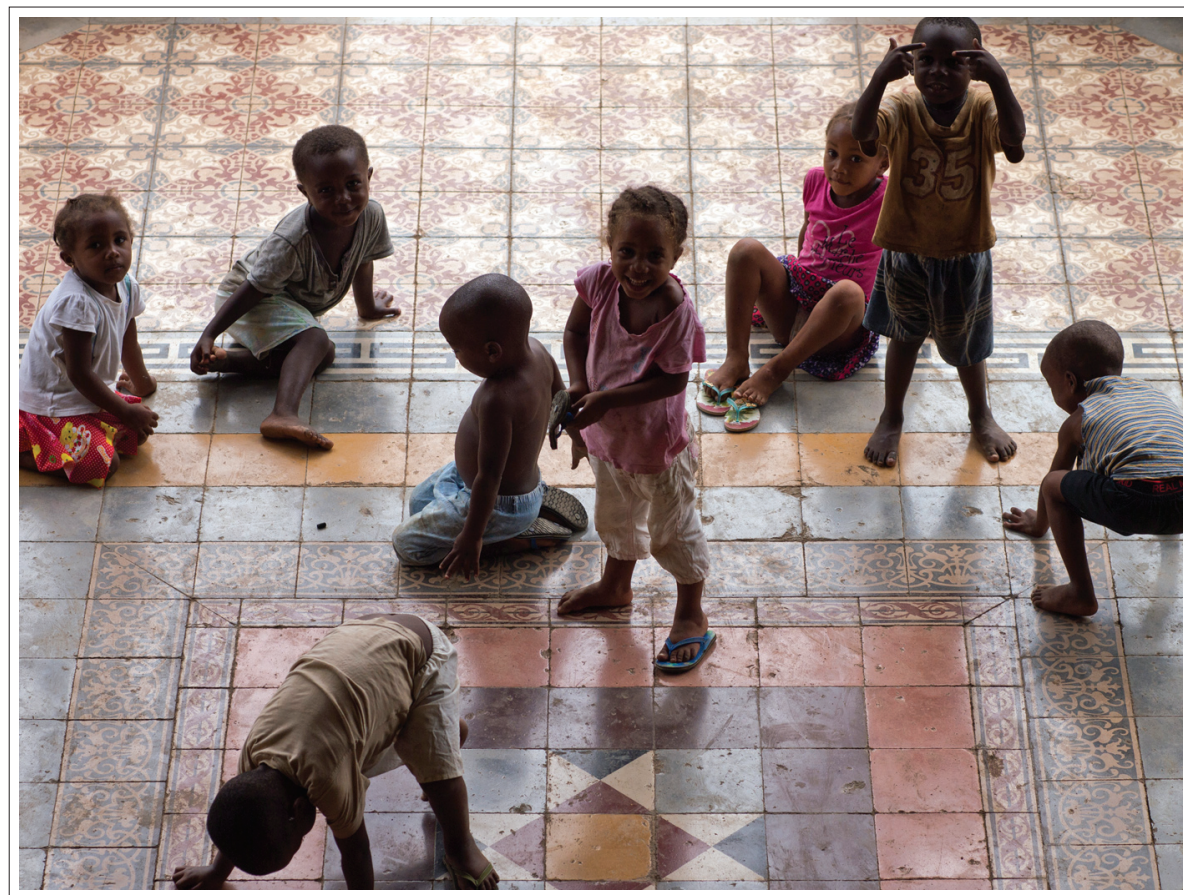

ZDJĘCIE 19. Boa Entrada dziś, hall budynku głównego zajęty przez dzieci jako plac zabaw. ŹRóDŁo: zbiory własne.

(...) portugalscy plantatorzy na wyspie Św. Tomasza wykorzystywali jako siłę roboczą niewolników sprowadzanych z kontynentu. To zatem za sprawą motywowanej chciwością i podsycanej rasizmem zbrodni niewolnictwa powstały wspaniałe budyn ki plantacyjne (...). Nikczemność zrodziła piękno, można by pomyśleć, ale tak naprawdę, każda roça to owoc pracy Afrykanów i to oni maja do niej prawo, bo portugalski ucisk nie stanowi żadnej zasługi, a jedynie winę. Takiż tok rozumowania ostatecznie zwyciężył i po uzyskaniu niepodległości plantacje zostały znacjonalizowane $w$ ramach przeprowadzonej tu reformy rolnej. Różny los spotkał poszczególne części plantacji. Część ziemi została rozdana chłopom, którzy wpierw byli jej użytkownikami, a potem stali się jej właścicielami. Część ziemi pozostaje własnością skarbu państwa i jest dzierżawiona lokalnym rolnikom i zagranicznym korporacjom, które inwestują tylko w uprawy produktów na eksport (kakao, kawa, palmy olejowe). Budynki dawnych sanzalli, czyli czworaków, zamieszkiwane są przez Saotomejczyków, którzy mają lepszą sytuację bytową, a którzy nie zdecydowali się na ucieczkę do miasta. Domy plantatorów natomiast są albo dzierżawione przez korporacje zagraniczne uprawiające kakao, albo stoją całkowicie opuszczone, albo są zamieszkiwane przez wiejską biedotę (Leve Leve Love, 2016).

Co jeszcze ważniejsze z punktu widzenia pedagogiki rzeczy, obie koncepcje mogą być uznane za inspiracje dla jej rozwoju. Jednak koncepcja Foucaulta jest albo „tylko” krytyczna, albo wręcz stanowić może intelektualny wehikuł coraz to bardziej zmyślnych form dominacji. Koncepcja Freirego stanowi 
natomiast pomysł na materialną odmianę krytyki społecznej, w której możliwości emancypacyjne sprawdzane są w praktyce społecznej przez rozwiązywanie problemów społecznych, leżących w strefie najbliższego rozwoju wspólnoty.

\section{BIBLIOGRAFIA}

Althusser, L. (2006). Ideologie i aparaty ideologiczne państwa. Warszawa: SKFM UW.

Almada Negreiros, J. (1895). Historia Ethnographica da Ilha de S. Thomé. Lizbona: Antiga Casa Bernard. Pozyskano z: https://archive.org/details/historiaethnogroonegrgoog/page/n5

Bentham, J. (1838). The Works Of. Edynburg: William Tait. Pozyskano z: http://lf-oll.s3. amazonaws.com/titles/1925/o872.04_Bk.pdf

Bernstein, B. (1990). Odtwarzanie kultury. Warszawa: PIW.

Biesta, G. (2010). A new logic of emancipation: The methodology of Jaques Rancière. Educational Theory, 60 (1), 39-59.

Bourdieu, P., Passeron, J.-C. (2006). Reprodukcja. Elementy teorii systemu nauczania. Warszawa: PWN.

Bowles, S., Gintis, H. (1976). Schooling in Capitalist America. Educational Reform and the Contradictions of Economic Life. Nowy Jork: Basic Books.

Bowles, S., Gintis, H. (2002). Schooling in Capitalist America Revisited. Sociology of Education, t. 75, 1, 1-18.

Brandão, C.R., Assumpção, R. (2009). Cultura Rebelde. Escritos sobre a Educação Popular ontem e agora. São Paulo: Ed,L.

Caldeira, A.M. (1999). Mulheres, sexualidade e casamento em São Tomé e Príncipe (séculos $X V-X V I I I)$. Lizbona: Cosmos.

Casement, R. i in. (1904). Correspondence and Report from His Majesty's Consul at Boma Respecting the Administration of the Independent State of Congo. Londyn: Majesty's Stationery Office. Pozyskano z: https://archive.org/details/CasementReport

Chutorański, M. (2015). Urządzenie (edukacyjne): sieci, dyskursy, ludzie, nie-ludzie. Teraźniejszość - Człowiek - Edukacja, 4 (72), 7-21.

Chutorański, M. (2016). Nie(tylko)ludzka pedagogika? W: K. Węc, A. Wierciński (red.), Ryzyko jako warunek rozwoju. Transformatywne aspekty edukacji (s. 256-271). Toruń: Adam Marszałek.

Chutorański, M. (2017). W stronę nie-antropocentrycznej ontologii tego, co edukacyjne. Teraźniejszość - Człowiek - Edukacja, 4 (80), 7-21.

Chutorański, M., Makowska, A. (2016). Pedagogika rzeczy (nie tylko) konsumowanych. Pare$z j a, 1(5), 66-78$.

Foucault, M. (200oa). „Rządomyślność”. W: M. Foucault, Filozofia, historia, polityka: wybór pism (s. 163-185). Warszawa-Wrocław: PWN.

Foucault, M. (20oob). Techniki siebie. W: M. Foucault, Filozofia, historia, polityka: wybór pism (s. 247-275). Warszawa-Wrocław: PWN.

Foucault, M. (2002). Archeologia wiedzy. Warszawa: „Altaya”.

Foucault, M. (2009). Nadzorować i karać. Narodziny więzienia. Warszawa: Aletheia.

Foucault, M. (2010). Bezpieczeństwo, terytorium, populacja. Warszawa: PWN.

Foucault, M. (2013). Kim Pan jest, profesorze Foucault? Debaty, rozmowy, polemiki. Kraków: Libron.

Freire, P. (1967). Educação como prática da liberdade. Rio de Janeiro: Paz e Terra. Pozyskano z: dhnet.org.br/direitos/militantes/paulofreire/livro_freire_educacao_pratica_liberdade. pdf

Freire, P. (1975). Pedagogia do Oprimido. Porto: Afrontamento. 
Freire, P. (1978). Cartas aos Animadores e às Animadoras Culturais. São Tomé: Ministério de Educação Nacional e Desporto.

Freire, P. (1979). W sprawie dialektycznego związku między nauczycielem i uczniem. W: A. Mońka-Stanikowa (red.), Oświata i wychowanie w toku przemian (s. 150-154). Warszawa: PWN.

Freire, P. (1989). A importáncia do ato de ler. São Paulo: Cortez. Pozyskano z: http://educacaointegral.org.br/wp-content/uploads/2014/10/importancia_ato_ler.pdf

Frynas, J.G., Wood, G., Soares de Oliveira R.M.S. (2003). Business and Politics in São Tomé e Príncipe: From Cocoa Monoculture to Petro-State. African Affairs, 102, 51-80.

Gerhardt, H.P. (1996). Arqueologia de um Pensamento. W: M. Gadotti (red.), Paulo Freire. Uma biobibliografia (s. 149-170). São Paulo: Cortez e IPF.

Granosik, M. (2018). Pożegnanie z Foucaultem. Governmentality i praca socjalna. Miscellanea Anthropologica et Sociologica, 19 (3), 169-188.

Giroux, H.A. (1983). Theories of Reproduction and Resistance In the New Sociology of Education: A Critical Analysis. Harvard Educational Review, Vol. 53, 3, 257-293.

Giroux, H.A. (2001). Theory and Resistance in Education. Towards a Pedagogy for the Opposition. Westport-Londyn: Bergin\&Garvey.

Higgs, C. (2012). Chocolate Islands. Cocoa, Slavery and Colonial Africa. Ohio: University Press.

Hodgson, N., Vlieghe, J., Zamojski, P. (2017a). Education and the Love for the World: articulating a post-critical educational philosoph. Foro de Educación, 16 (24), 7-20.

Hodgson, N., Vlieghe, J., Zamojski, P. (2017b). Manifesto for a Post-Critical Pedagogy. Earth: Punctum Books.

Horkheimer, M. (1985). Nowe pojęcie ideologii? W: A. Chmielecki, S. Czerniak, J. Niżniak, S. Rainko (red.), Problemy socjologii wiedzy. Warszawa: PWN.

Laclau, E. (2009). Rozum populistyczny. Wrocław: DSW.

Latour, B. (2010). Splatajac na nowo to, co społeczne: wprowadzenie do teorii aktora-sieci. Kraków: Universitas.

Latour, B. (2011). Nigdy nie byliśmy nowocześni: studium z antropologii symetrycznej. Warszawa: Oficyna Wydawnicza.

Mannheim, K. (1992). Ideologia i utopia. Lublin: Test.

Marks, K., Engels, F. (1981). Dzieła wybrane (t. I). Warszawa: KiW.

Ministério de Educação Nacional e Desporto (1978). A Luta Continua. Segundo Caderno de Cultura Popular. São Tomé.

Ministério de Educação Nacional e Desporto (1979). A Luta Continua. Quarto Caderno de Cultura Popular. São Tomé.

Ministério de Educação Nacional e Desporto (1980). A Luta Continua. Primeiro Caderno de Cultura Popular. São Tomé.

Monteiro de Mendonça, H.J. (1907). The Boa Entrada Plantations: S. Thomé, Portuguese West Africa, „la Perle des Colonies Portugaises”. Londyn, Edynburg: Oliphant Anderson \& Ferrier. Pozyskano z: https://archive.org/details/boaentradaplantoowyllgoog/page/n5

Pape, D., Rebelo de Andrade, R. (2013). As Roças de São Tomé e Príncipe. Lizbona: tinta-dachina.

Piketty, T. (2015). Kapitał w XXI wieku. Warszawa: Wydawnictwo Krytyki Politycznej.

Rancière, J. (1991). The Ignorant Schoolmaster. Five Lessons in Intellectual Emancipation. Stanford: University Press.

Siebert, G. (1999). Comrades, Clients and Cousins. Colonialism, Socialism and Democratization in São Tomé and Príncipe. Leiden: Brill.

Sloterdijk, P. (2008). Krytyka cynicznego rozumu. Wrocław: Wydawnictwo DSW.

Sousa e Faro, J.D.C. (1908). A Ilha de S. Thomé e a Roça Agua-Izé. Lizbona: Tipografia do Annuario Commercial. 
Stańczyk, P. (2017). A Luta Continua. Cadernos de Cultura Popular: podręcznik do alfabetyzacji i postalfabetyzacji dorosłych współautorstwa Paula Freire jako przykład emancypacyjnej edukacji ludowej. Teraźniejszość - Człowiek - Edukacja, 2 (78), 29-51.

Stańczyk, P. (2018a). Freirego Suchodolskim - Suchodolskiego Freirem: pedagogika materialistyczna i krytyka ideologii. Teraźniejszość - Człowiek - Edukacja, 2 (82), 7-30.

Stańczyk, P. (2018b). Uciśnieni, historia i społeczna zmiana. Historiozofia w filozofii wychowania P. Freirego: pojęcie historii jako możliwości. Forum Oświatowe, 30 (1), 53-72.

Starego, K. (2016). Poza dyskurs kompetencji w edukacji krytycznej. „Trzeci termin” oraz Paula Freirego i Jaquesa Rancière’a idea dialogu „zapośredniczonego”. Forum Oświatowe, 28 (1), 33-53.

Szwabowski, O. (2016). Dociekania robotnicze: analiza filozoficzna. Forum Oświatowe, Vol. 28, 1 (55), 77-94.

Suchodolski, B. (1957). U podstaw materialistycznej teorii wychowania. Warszawa: PWN.

Torres, C.A. (1996). Uma biografia intelectual. W: M. Gadotti (org.), Paulo Freire. Uma biobibliografia (s. 117-148). São Paulo: Cortez e IPF.

Vlieghe, J. (2016). Rethinking emancipation with Freire and Rancière. A plea for a thing-centered pedagogy. Educational Philosophy and Theory, 50 (10), 1-11.

Žižek, S. (2008). W obronie przegranych spraw. Warszawa: Wydawnictwo Krytyki Politycznej.

\section{INNE ŹRÓDEA}

Leve Leve Love: https://www.facebook.com/LeveLeveLove/posts/579912798844211?__tn__=K-R

\section{DOKUMENTACJA FOTOGR AFICZNA}

Zdjęcia 1-10 - reprodukcja: Anita Wasik

Zdjęcia 11, 12, 18 i 19 - autorka: Anita Wasik

Zdjęcia 13-17 - Centro de Referência Paulo Freire [www.acervo.paulofreire.org]

\section{SUMMARY}

Freire versus Foucault:

Plantations, Slavery and Thing-centered Pedagogy

The main purpose of this article is to compare Paulo Freire's and Michel Foucault's philosophies of education using the example of basic literacy campaign at the Democratic Republic of São Tomé and Príncipe (STP). Using the archaeology of knowledge, the author intends to discover certain textual layers. The first layer (from the beginning of the $2 \mathrm{O}^{\text {th }}$ century) includes reports on labour conditions in the quasi-slavery system in Portuguese plantations and the answers published by Portuguese platnation owners. The organisation of labour and descriptions of native workers from that period are similar to Foucault's concept of discipline and punishment. The second layer contains texts from Freire's basic literacy campaign and it shows that using Foucault's concept to analyse handbooks from the basic literacy campaign diminishes the meaningfulness of emancipatory education. In conclusion, the author attempts to decline - from the pragmatic point of view - the possible critique of Freire's concept with the use of Foucault's concept by finding the solution in emancipatory thing-centred pedagogy.

KEYWORDS: Paulo Freire, Michel Foucault, emancipatory pedagogy, discipline and punishment, thing-centred pedagogy, materialist pedagogy 